\title{
Socioeconomic, Nutritional Profile Correlates with Morbidity Risks and Quality of Health Status among Elderly Residing at Old Age Home \& Residence from Different Region of South Karnataka
}

\author{
Pooja Anudhar $\mathbf{G}^{1}$, Sushma B. $\mathrm{V}^{2}$ \\ ${ }^{1}$ Research Scholar, Department of Nutrition \& Dietetics, Faculty of Life Sciences, JSSAHER, \\ ${ }^{2}$ Assistant Professor, Department of Nutrition \& Dietetics, Faculty of Life Sciences JSSAHER, Mysore.
}

Corresponding Author: Pooja Anudhar G

\begin{abstract}
Ageing is the multidimensional process in humans with changes occurring in physical, psychological and social aspects which increase their proneness to health ailments. The associated functional impairment and physical inability will influence on their absorption and metabolism leading to the changes in nutritional status. Epidemiological study was conducted among the elderly subjects with respective to understand the quality of health in relation to the nutritional profile. Using a purposive randomized sampling technique, the elderly subjects were selected and assessed for the nutrition and health condition. The investigation comprises approximately 90 subjects of old age institutions and 90 subjects of residents from different domiciles. The study was conducted using standardized validated tools and checklist with oral interview technique and one to one interactions.

Findings: In accordance with the body mass evaluation; approximately 59\% elderly living at own houses were under Grade 1, Grade 2 and Grade 3 obesity in comparison to their counterpart. Medical health records indicated iron deficiency anemia among $10 \%$ of subjects. Gastritis, Diabetes, hypertension, arthritis was observed to be the major health problems. Comparatively $64 \%$ male elderly from household had oral problems and underwent for dentures. Often had three meal patterns in a day. Henceforth, there is a need to understand and address on the nutritional needs, etiology and demographic characteristics interlinked with comorbidities and health disabilities among aging population. Evidently a significant association was noticed between nutritional status on morbidities and health quality among elderly.
\end{abstract}

Keywords: Old age home, elderly, ageing, nutritional profile, quality of health

\section{INTRODUCTION}

Ageing is a natural physiological process associated with physiological, psychological, social, dietary, and environmental factors. Ageing can be described as a process of intrinsic deterioration with time that causes decreases in strength, endurance and fecundity, and increases in disease susceptibility and likelihood of death. Elderly population growth size was noted to be 5 to $5.4 \%$ during 1901 to 1951.

Resultantly during 2001 onwards elderly population growth size had increased to $7 \%{ }^{[1]}$. It also estimated to be $12 \%$ increased by $2030^{[2]}$. According to 2001 census, Karnataka is the sixth most populous State in terms of proportion of aged population in India after Kerala (10.5 per cent), Himachal Pradesh and Punjab (9 
per cent), Tamil Nadu (8.8 per cent), Maharashtra (8.7 per cent), Goa and Pondicherry ( 8.3 per cent) Karnataka has 7.7 per cent of the old age population, which is above the national average of 7.6 per cent [3]

With a rising percentage of elderly population, epidemiologists, researchers, demographers and clinicians have focused their attention towards elderly care health issues and various problems associated with ageing and numerous implications of this demographic transition. In recent years often elderly experience age related problems and require a multi-sectoral approach involving from various disciplines of health, psychology, nutrition, sociology and social sciences.

Often Urbanization has greatly influenced productivity and living practices in elderly population. The traditional way of living in joint family has been decreasing and sharing with institutions like old age homes. Elderly population experience isolation from family, relatives and society then also with financial dependency on children. As they live alone and situation get worsen with illness, they suffer from one or more communicable and noncommunicable diseases. Along with these, vision and hearing impairments are the most common health problems which worsen the circumstances ${ }^{[4]}$.

Physiological changes in elderly are the resultant for the onset of age related disease progression \& malnutrition, especially in older adults living alone. Typically, poverty, social and food insecurity are noted be the underlying reason for the increased lifestyle disease and fatality in elderly. Markedly poor productivity, lack of income, poor self-care, are the significant factors causing illness, health disabilities and increased fatality in elderly ${ }^{[5]}$.

Nutritional status has the major role in promoting health status and quality of life [6]. Older people are vulnerable to malnourishment with increased morbidity and mortality risks. Increasing in fall, several infections, poor wound healing, loss of energy are sign of undernourishment. Over nutrition like obese causes the diabetes, hypertension and other morbid profiles are also causing the malnourishment in the elderly ${ }^{[7]}$. Early nutritional screening and intervention approach could meet physiological requirements and improve quality of life in an individual.

\section{Research Objectives}

* Assessing General health and demographic profile among elderly from different domiciles

* Screening comorbidities and nutritional etiology among elderly from different domiciles

\section{METHODOLOGY}

The proposed investigation is a need based clinical experimental research, Cross sectional Epidemiological study.

Study area: Elderly living in Old age home $(\mathrm{OAH}) \&$ Residence $(\mathrm{R})$ located in rural \& urban areas from Mysore \& Mandya district of Karnataka.

Study duration: 3 months.

Research criteria: Inclusion criteria: a) Age $\geq 60$ years, b) Permanent residents ( $\geq 5$ years), c) Written informed consent. Exclusion criteria: a) Not willing to participate in the study, b) Critically ill.

Target population size: Around 180 elderly subjects were examined on a pretested questionnaire by face to face interview method using purposive randomized sampling technique

Demographic screening: demographic characteristics including type of family, economic, literacy and occupation status was screened using standardized checklist based on the interview method

Subjective global assessment: General health screening including Current medical condition, disease onset of occurrence, clinical manifestation and comorbidity, medical care were screened 


\section{Anthropometry screening:}

Body height was measured using wall measuring tape. Participants were made to stand without footwear with heels and toes together. Head and shoulder were supposed to touch the wall. Scale was lowered from the height compressing the hair and tape and finding the top of the head and reading was measured and recorded. Body Weight was measured by made subjects to stand on the standardized weighing scale with minimum cloth and barefoot, and recorded the weight. This was followed by calculating the Body Mass Index (BMI) Data was collected by the researcher independently. Waist and hip circumferences were also measured with minimum cloth and recorded the mean of 3 measurements and calculated $\mathrm{W} / \mathrm{H}$ ratio based on the standard values ${ }^{[8]}$.

Dietary adequacy: type and amount of food consumption using standardized food frequency questionnaire

\section{RESULTS \& DISCUSSION}

Table 1: Demographic profile of elderly from different domicile.

\begin{tabular}{|c|c|c|c|c|c|c|c|c|}
\hline \multirow[t]{4}{*}{ Demographic Characteristics } & \multicolumn{8}{|c|}{ Total Population $(N=180)$} \\
\hline & \multicolumn{4}{|c|}{ Old Age Home } & \multicolumn{4}{|c|}{ Residents $\quad n=90$} \\
\hline & \multicolumn{2}{|c|}{ Male $(n=32)$} & \multicolumn{2}{|c|}{ Female $(n=58)$} & \multicolumn{2}{|c|}{$\operatorname{Male}(n=36)$} & \multicolumn{2}{|c|}{ Female $(n=54)$} \\
\hline & $\%$ & $n$ & $\%$ & $n$ & $\%$ & $n$ & $\%$ & $n$ \\
\hline \multicolumn{9}{|l|}{ Age years } \\
\hline Young old (60-69 yrs) & 19.0 & 6 & 21.0 & 12 & 58.0 & 21 & 61.0 & 33 \\
\hline Old old (70-79 yrs) & 38.0 & 12 & 43.0 & 25 & 39.0 & 14 & 28.0 & 15 \\
\hline Oldest old (80 yrs\& above) & 43.0 & 14 & 36.0 & 21 & 3.0 & 01 & 11.0 & 06 \\
\hline \multicolumn{9}{|l|}{ Religion: } \\
\hline Hindu & 88.0 & 28 & 95.0 & 55 & 100.0 & 36 & 100.0 & 54 \\
\hline Christian & 12.0 & 04 & 5.0 & 03 & $\mathrm{NO}$ & $\mathrm{NO}$ & $\mathrm{NO}$ & $\mathrm{NO}$ \\
\hline Muslim & $\mathrm{NO}$ & $\mathrm{NO}$ & $\mathrm{NO}$ & $\mathrm{NO}$ & $\mathrm{NO}$ & $\mathrm{NO}$ & $\mathrm{NO}$ & $\mathrm{NO}$ \\
\hline Other & NO & NO & NO & NO & NO & $\mathrm{NO}$ & NO & $\mathrm{NO}$ \\
\hline \multicolumn{9}{|l|}{ Family type } \\
\hline Extended & 15.0 & 47 & 57.0 & 33 & 44.0 & 16 & 50.0 & 27 \\
\hline Nuclear & 41.0 & 13 & 31.0 & 18 & 44.0 & 16 & 35.0 & 19 \\
\hline Joint & 12.0 & 04 & 12.0 & 07 & 12.0 & 04 & 15.0 & 08 \\
\hline \multicolumn{9}{|l|}{ Marital status } \\
\hline Married & 43.0 & 14 & 21.0 & 12 & 97.0 & 35 & 50.0 & 27 \\
\hline Un married & 11.0 & 04 & 9.0 & 05 & $\mathrm{NO}$ & $\mathrm{NO}$ & $\mathrm{NO}$ & $\mathrm{NO}$ \\
\hline Widowed/widower & 43.0 & 14 & 70.0 & 41 & 3 & 01 & 50.0 & 27 \\
\hline Separated & 3.0 & 01 & $\mathrm{NO}$ & $\mathrm{NO}$ & $\mathrm{NO}$ & $\mathrm{NO}$ & $\mathrm{NO}$ & $\mathrm{NO}$ \\
\hline Divorced & NO & $\mathrm{NO}$ & $\mathrm{NO}$ & $\mathrm{NO}$ & $\mathrm{NO}$ & $\mathrm{NO}$ & $\mathrm{NO}$ & $\mathrm{NO}$ \\
\hline \multicolumn{9}{|l|}{ Education: } \\
\hline No education & 9.0 & 03 & 22.0 & 13 & 19.0 & 07 & 58.0 & 31 \\
\hline Only know to read \& write & 16.0 & 05 & 22.0 & 13 & $\mathrm{NO}$ & $\mathrm{NO}$ & 16.0 & 09 \\
\hline primary & 3.0 & 01 & 5.0 & 03 & 0 & 0 & 2.0 & 01 \\
\hline Upper primary & 19.0 & 06 & 14.0 & 08 & 11.0 & 04 & 11.0 & 06 \\
\hline Secondary & 16.0 & 05 & 28.0 & 16 & 42.0 & 15 & 13.0 & 07 \\
\hline Higher secondary & 16.0 & 05 & 5.0 & 03 & 6.0 & 02 & $\mathrm{NO}$ & $\mathrm{NO}$ \\
\hline Graduation & 15.0 & 05 & 4.0 & 02 & 16.0 & 06 & NO & NO \\
\hline Post graduation & 3.0 & 01 & $\mathrm{NO}$ & $\mathrm{NO}$ & 3.0 & 01 & $\mathrm{NO}$ & $\mathrm{NO}$ \\
\hline Diploma & 3.0 & 01 & NO & $\mathrm{NO}$ & 3.0 & 01 & $\mathrm{NO}$ & $\mathrm{NO}$ \\
\hline
\end{tabular}

Need based epidemiological study was conducted in Old Age Home (OAH) \& Household residence (HR) located in rural \& urban area of South India Karnataka. Investigation comprised approximately 180 elderly populations both male and female based on the purposive randomized sampling technique. Out of 90 elderly from OAHs, 64\% were females and $36 \%$ were males. Relatively out of 90 elderly from residence; $60 \%$ were females and $40 \%$ were males. Supportive study by Zalavadiya et al reports ${ }^{[8]}$; Out of 88 OAHs elderly, $65.9 \%$ were females and $3034.1 \%$ were males. From the findings it has been noted that a higher percent population were females in comparison to males from different domicile

Based on WHO Criteria the elderly population was categorized as Young old, 
Old old and oldest old. From the population based community research conducted in Budgam District ( $\mathrm{J} \& \mathrm{~K})$; majority of the population were between the age group of 60-64 years and were referred as "young old" ${ }^{[9]}$. Research findings by Zalavadiya et al $2016^{[10]}$ showed that $76.7 \%$ elderly males living in old age homes were 'young old' as compared to $84.4 \%$ elderly were from own residence in the community. From the investigation it has been observed that greater 60 percent of the elderly belonged to the "young old" age category at residents' domicile. Majority of the OAH elderly belonged to Old old (41\%) \& oldest old (39\%) as compared to elderly living at their own residence.

In relevance to the research perceptiveness the demographic characteristics including type of family, economic and literacy status and general health status were screened. Etiological factors responsible for psychological instability \& age related problem are Industrialization, urbanization and migration resulting to the negative impact on quality of health in elderly. Evidently the weakening of the traditional bonding of joint family could be the reason for poor quality of life in elderly ${ }^{[11]}$. Notably the literacy level of $\mathrm{OAH}$ females $(62 \%)$ was higher than other respondents ${ }^{[12]}$. Findings from the study reports that $9.2 \%$ of female from rural area of Varanasi were literate ${ }^{[13]}$.

Among the total elderly, 30\% were illiterate especially the proportion of illiterates were higher among resident's females $(58 \%)$ than OAH. Most of the respondents belonged to nuclear family $(37 \%)$ in both the domicile. From the observation percentage of elderly living in joint family noticed to be less.

Table 2: Body Mass profile of elderly from different domicile [14]

\begin{tabular}{|c|c|c|c|c|c|c|c|c|}
\hline \multirow[t]{4}{*}{$B M I$} & \multicolumn{8}{|c|}{ Total Population $N=180$} \\
\hline & \multicolumn{4}{|c|}{ Old Age Home $\quad n=90$} & \multicolumn{4}{|c|}{ Residence $\quad n=90$} \\
\hline & \multicolumn{2}{|c|}{ Male \% $(n=32)$} & \multicolumn{2}{|c|}{ Female $n=58$} & \multicolumn{2}{|c|}{ Male $n=36$} & \multicolumn{2}{|c|}{ Female $n=54$} \\
\hline & $\%$ & $\mathbf{n}$ & $\%$ & $n$ & $\%$ & $n$ & $\%$ & $n$ \\
\hline$<18.5$ (under nutrition) & 6.0 & 2 & 9.0 & 05 & 3.0 & 01 & 4.0 & 02 \\
\hline 18.5 to 22.9 Normal & 37.0 & 12 & 26.0 & 15 & 19.0 & 07 & 15.0 & 08 \\
\hline 23 to 24.9 (Over weight) & 19.0 & 06 & 17.0 & 10 & 31.0 & 11 & 15.0 & 08 \\
\hline 25 to 29.9 (Grade 1 obesity) & 25.0 & 08 & 28.0 & 16 & 36.0 & 13 & 33.0 & 18 \\
\hline 30 to 34.9 (Grade 2 obesity & 9.0 & 03 & 12.0 & 07 & 8.0 & 03 & 20.0 & 11 \\
\hline 35 to 40 (Grade 3 obesity) & 3 & 01 & 8.0 & 05 & 3.0 & 01 & 13.0 & 07 \\
\hline \multirow[t]{2}{*}{$\begin{array}{l}\text { T test } \\
\text { aat } p<0.05\end{array}$} & & $\begin{array}{l}\mathrm{t} \text { value } \\
\mathrm{p} \text {-value }\end{array}$ & $\begin{array}{l}= \\
=0.002\end{array}$ & 4.102 & \multicolumn{4}{|c|}{$\begin{array}{ll}\mathrm{t} \text { value }= & 1.731 \\
\mathrm{p} \text {-value }= & 0.094\end{array}$} \\
\hline & & & $\begin{array}{l}\mathrm{t} \text { value } \\
\mathrm{p} \text {-value }\end{array}$ & $\begin{array}{l}=2.8 \\
=0.0\end{array}$ & & & & \\
\hline
\end{tabular}

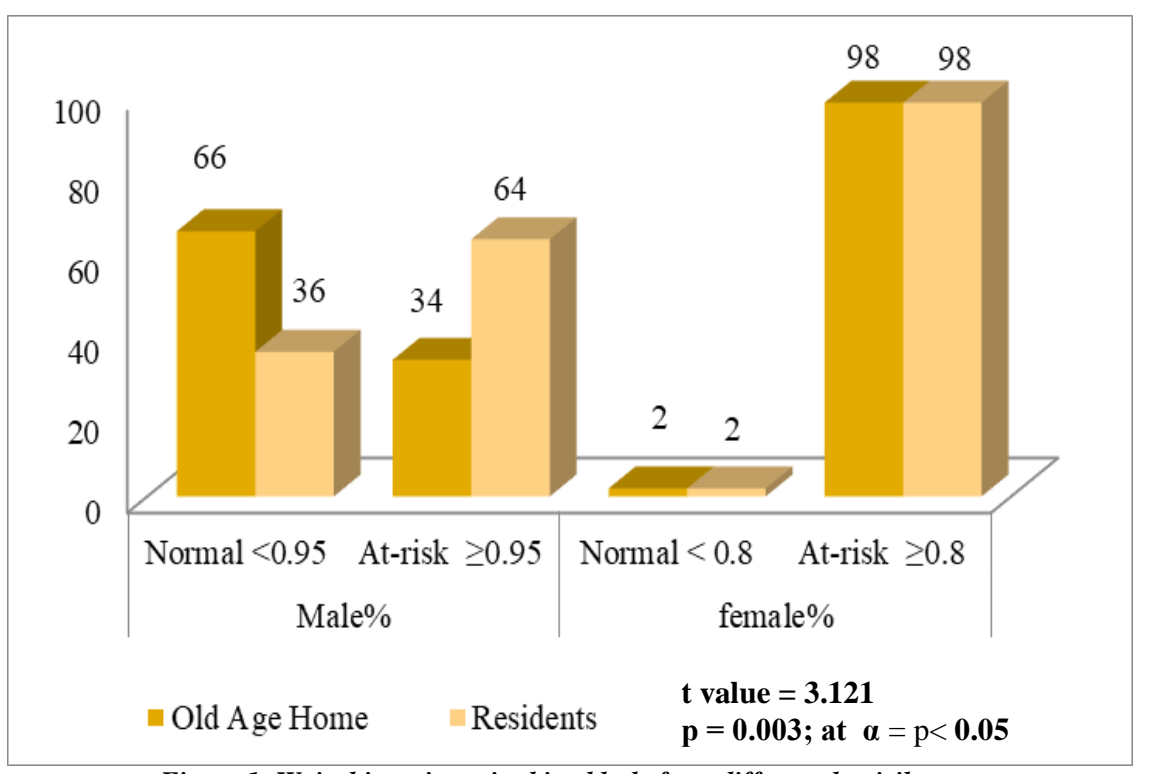

Figure 1: Waist hip ratio noticed in elderly from different domicile 
Screening on body mass status among elderly from different domicile reports that, $30 \%$ OAH elderly were normal than their counter parts living at home. In accordance with the body mass evaluation; approximately $59 \%$ elderly living at own houses were under Grade 1, Grade 2 and Grade 3 obesity in comparison to their counterpart. Resultantly these are underlying risk factors leading to malnutrition and chronic morbidity issues. Notably 83 percent elderly living at their own residence were malnourished in the form of underweight, overweight or obese. Most of the females residing at house were overweight $(33.0 \%)$ than the $\mathrm{OAH}$ participants. Findings by Khole \& Soletti, $2018^{[15]}$; reports the higher incidence of malnutrition risk in elderly i.e underweight (11.5\%), overweight $(26.2 \%)$ and obesity (7.7\%). Evidence shows that more number of males (15.5\%) were underweight compared to females (8.3\%). Comparatively, higher percent of females (27.8\%) were overweight in comparison to males $(24.1 \%)$.

In line, OAH elderly were normal compared to their residence domicile counterparts.

Supportive dietary needs, appropriate lifestyle and physical activities are the reasons for achieving normal body mass in elderly. Significantly higher proportion of OAH elderly had normal BMI range than their counter parts from residents' domicile ( $\mathrm{p}=0.031$; at $\alpha=$ $\mathrm{p}<00.05)$.
Interestingly waist hip ratio parameter screened among the respondents revealed $60 \%$ OAH males to be normal. Statistically $98 \%$ females especially living at residential zone were higher at risk of central obesity $(p=0.003$ at $\alpha=p<0.05)$.

Evidently supporting evidence from Pai, $2011^{[2]}$ has revealed the $\mathrm{WH}$ ratio parameter to be one of the underlying risk factor among elderly staying at home leading to the trunk development and metabolic syndromes.

As mentioned in table 3, Common comorbidities noticed in elderly from different domicile were Diabetes, Hypertension followed by Gastritis i.e 33\%, $18 \%$ and $54 \%$ respectively. To a certain extent 24 percent females from residence experienced hypertension risk than their counter parts from $\mathrm{OAH}$ i.e 9\%. Gastritis was the most regular health issues among all respondents. Wherein higher percent of elderly were provided with medications. Prevalence of Hypertension \& Diabetes was the major common health issues in elderly revealed from the similar findings by ${ }^{[16]}$. Research evidences from Rafiq, 2016) reported an increased morbidity profile i.e Hypertension (37.3\%) and diabetes (12.7\%) among elderly.

In present study all the respondents were having one or more comorbidities and $58 \%$ of the $\mathrm{OAH}$ participants were having one or the other issues than home residence. Statistically the prevalence of morbidity level found to be higher among $\mathrm{OAH}$ participants in comparison to home residence $(p$-value $=0.018$; at $\alpha=p<0.05)$

Table 3: Comorbidity profile according to the residential zone.

\begin{tabular}{|c|c|c|c|c|c|c|c|c|}
\hline \multirow[t]{3}{*}{ Comorbidity profile } & \multicolumn{4}{|c|}{$O A H$} & \multicolumn{4}{|l|}{ Residence } \\
\hline & \multicolumn{2}{|l|}{ Male } & \multicolumn{2}{|c|}{ Female } & \multicolumn{2}{|l|}{ Male } & \multicolumn{2}{|c|}{ Female } \\
\hline & $\%$ & $n$ & $\%$ & $n$ & $\%$ & $n$ & $\%$ & $n$ \\
\hline Diabetes & 34.0 & 11 & 33.0 & 19 & 39.0 & 14 & 9.0 & 05 \\
\hline Hypertension & 38.0 & 12 & 9.0 & 05 & 33.0 & 12 & 24.0 & 13 \\
\hline Liver problems & $\mathrm{NO}$ & $\mathrm{NO}$ & $\mathrm{NO}$ & $\mathrm{NO}$ & 9.0 & 03 & $\mathrm{NO}$ & $\mathrm{NO}$ \\
\hline Arthritis & 3.0 & 01 & 3.0 & 02 & $\mathrm{NO}$ & $\mathrm{NO}$ & 2.0 & 01 \\
\hline Gastritis & 47.0 & 15 & 59.0 & 34 & 25.0 & 09 & 28.0 & 15 \\
\hline Asthma & 3.0 & 01 & 7.0 & 04 & $\mathrm{NO}$ & $\mathrm{NO}$ & 2.0 & 01 \\
\hline T test & \multicolumn{2}{|c|}{$\begin{array}{l}\mathrm{t} \text { value } \\
\mathrm{p} \text {-value }\end{array}$} & $\begin{array}{l}=3 . \\
=0 .\end{array}$ & & \multicolumn{4}{|c|}{$\begin{array}{ccc}\mathrm{t} \text { value } & =3.117 \\
\mathrm{p} \text {-value } & =0.010\end{array}$} \\
\hline$\alpha$ at $p<0.05$ & \multicolumn{8}{|c|}{$\begin{aligned} \mathrm{t} \text { value } & =2.777 \\
\mathrm{p} \text {-value } & =0.018\end{aligned}$} \\
\hline
\end{tabular}


Data presented in Table 4 explains the common health problems experienced among elderly with other comorbid condition. Noticeably hearing and vision impairment were the common risk exhibited among all the respondents. Especially elderly living in old age home had hearing problem and vision impairment than the household counterpart. A cross sectional study conducted in rural and urban slums, 83.3\% population had vision impairment.
Approximately $63.1 \%$ population selfreported hearing impairment; especially higher proportion of female population had hearing impairment compared to male $(\mathrm{p}=$ 0.028 ; at $\alpha=p<0.05$ ). Often $64 \%$ male elderly from household had oral problems and underwent for dentures. Comparatively cross sectional finding reveals that $32.6 \%$ elderly noted to experience dental problem [12]

Table 4: Common health problems in elderly.

\begin{tabular}{|c|c|c|c|c|c|c|c|c|}
\hline \multirow{3}{*}{ Common health problems } & \multicolumn{4}{|l|}{$O A H$} & \multicolumn{4}{|c|}{ Residence } \\
\hline & \multicolumn{2}{|l|}{ Male } & \multicolumn{2}{|c|}{ Female } & \multicolumn{2}{|l|}{ Male } & \multicolumn{2}{|c|}{ Female } \\
\hline & $\%$ & $\mathbf{n}$ & $\%$ & $\mathbf{n}$ & $\%$ & $\mathbf{n}$ & $\%$ & $\mathbf{n}$ \\
\hline Hearing & 84.0 & 27 & 79.0 & 46 & 39.0 & 14 & 33.0 & 18 \\
\hline Vision & 92.0 & 30 & 98.0 & 57 & 53.0 & 19 & 61.0 & 33 \\
\hline Joints pain & 72.0 & 23 & 79.0 & 46 & 83.0 & 30 & 80.0 & 43 \\
\hline Poor attention & 28.0 & 09 & 33.0 & 19 & 8.0 & 03 & 4.0 & 02 \\
\hline Trembling & 22.0 & 07 & 14.0 & 8 & 30.0 & 11 & 20.0 & 11 \\
\hline Weak memory & 38.0 & 12 & 26.0 & 15 & 58.0 & 21 & 57.0 & 31 \\
\hline Headache & 19.0 & 06 & 5.0 & 3 & 22.0 & 08 & 54.0 & 29 \\
\hline Cold \& Cough & $\mathrm{NO}$ & $\mathrm{NO}$ & $\mathrm{NO}$ & $\mathrm{NO}$ & 22.0 & 08 & 18.0 & 10 \\
\hline Oral problem & 47.0 & 15 & 43.0 & 25 & 64.0 & 23 & 55.0 & 30 \\
\hline Fever & 28.0 & 09 & 38.0 & 22 & 50.0 & 18 & 46.0 & 25 \\
\hline Skin problem & 9.0 & 03 & 3.0 & 02 & 8.0 & 03 & 22.0 & 12 \\
\hline Breathing & $\mathrm{NO}$ & $\mathrm{NO}$ & 2.0 & 01 & 8.0 & 03 & 7.0 & 04 \\
\hline Diarrhea & 3.0 & 01 & $\mathrm{NO}$ & $\mathrm{NO}$ & 3.0 & 01 & $\mathrm{NO}$ & $\mathrm{NO}$ \\
\hline Constipation & $\mathrm{NO}$ & $\mathrm{NO}$ & 14 & 08 & 8.0 & 03 & 9.0 & 05 \\
\hline \multirow{2}{*}{$\begin{array}{l}\text { T test } \\
\alpha \text { at } p<0.05\end{array}$} & \multicolumn{4}{|c|}{$\begin{array}{ll}t \text { value } & =3.53 \\
p \text {-value } & =0.006\end{array}$} & \multicolumn{4}{|c|}{$\begin{array}{l}t \text { value }=2.908 \\
p \text {-value }=\end{array}$} \\
\hline & & & & $\begin{array}{l}t v a \\
p-v e\end{array}$ & $\begin{array}{l}= \\
=\end{array}$ & 2.54 & 0.02 & \\
\hline
\end{tabular}

Around 52\% elderly from urban area had a practice of drinking 5 glasses of water per day. Majority of the elderly population had three meal pattern per day. Around 26\% Elderly working in the agricultural land had two meals pattern per day. Preference for soft food and reduced portion size as compared to the recommendation was observed due to dental problems among the elderly. Elderly staying at old age home consumed milk everyday especially elite class old age homes. Interestingly all participants had consumption of one or two kind of vegetables, legumes from their regular diet. Considerably $24 \%$ had regular fruit consumption and $66 \%$ had a consumption of poultry, meat and fish weekly once or twice.

\section{CONCLUSION}

Elderly population is at risk of under nutrition due to physical, cognitive as well as functional decline. Increasing ill health and increasing disability are linked with nutritional risk indicators. The potential risk factors of malnutrition are multiple: reduced food intake due to loss of appetite, episodes of fasting, poor dentition, swallowing difficulties, inability to eat independently, digestive disorders, chronic diseases and depression.

Food based approach is thought to be a sustainable approach in combating non communicable diseases. Several foods are thought to possess antidiabetic and hypocholestrolemic activity by means of using whole grains, millets, pseudo cereals, legumes, soybean, flaxseed vegetable and Green leafy vegetables. Existing knowledge about nutrition and aging suggests nutrition to be the strong marker towards substantial impact on the functional health status of older individuals. Investigation elicited the 
Pooja Anudhar G et.al. Socioeconomic, nutritional profile correlates with morbidity risks and quality of health status among elderly residing at old age home \& residence from different region of South Karnataka.

multidimensional etiological factors linked with prevalence and malnutrition in elderly.

\section{Acknowledgement: None}

\section{Conflict of Interest: None}

\section{Source of Funding: None}

\section{Ethical Approval: Approved}

\section{REFERENCES}

1. Banker, K., Prajapati, B., \& Kedia, G. Study Of Health Profile Of Residents Of Geriatric Home In Ahmedabad District. Natl J Community Med . 2011;2(3), 5.

2. Pai, M. K. Comparative Study Of Nutritional Status Of Elderly Population Living In The Home For Aged Vs Those Living In The Community. Biomedical Research. 2011 22(1), 8.

3. Shivalingappa, B. N. The Pattern Of The Distribution Of Aged Population In Rural Karnataka : A Spatial Analysis. J Rural Dev. 2011;30(4), 14.

4. Ingle, G. K., \& Nath, A. Geriatric health in India: Concerns and solutions. Indian $\mathbf{J}$ Community Med. 2008; 33(4), 214. https://doi.org/10.4103/0970-0218.43225

5. Meenu, K., \& Amrit, V. Assessment Of Malnourishment In Elderly Of Rural Punjab. 2014;5(2), 5.

6. Abraham, J., N., N., Johns, F., Aiyappan, R., M., M., Shibu, P., \& Mathew, E. Nutritional status of older adults in a community in Pathanamthitta district of Kerala. J Res Med Sci. 2017; 6(1), 210. https://doi.org/10.18203/23206012.ijrms20175721

7. Leslie, W., \& Hankey, C. Aging, Nutritional Status and Health. Healthcare. 2015;3(3), 648-658.

https://doi.org/10.3390/healthcare3030648

8. Zalavadiya DD, Banerjee A, Joshi NB, Bhola CN, Sheth AM. A Comparative Study of Morbidity Profile of Elderly Residing in Old Age Homes and in the Community of a Tier-II City in India. Natl J Community Med. 2018;9(7):480- 485
9. Singh, D. R., \& Shrestha, S. Nutritional status of senior citizens living in old age homes of Kathmandu metropolitan municipality. Int J Community Med Public Health. 2016;3(7), 1707-1715. https://doi.org/10.18203/23946040.ijcmph20162032

10. Dipeshkumar D. Zalavadiya, Anupam Banerjee, Niravkumar B. Joshi, Chirag N. Bhola, Ankit M. Sheth, Matib Rangoonwala. A Comparative study of the Socio demographic and activity profile of elderly residing in Old Age Homes and in the Community of Rajkot, Gujarat, India. Sch. J. Appl. Med. Sci. (2016);4(8D):29912995

11. Aruna Dubey, Seema Bhasin, Neelima Gupta and Neeraj Sharma. A Study of Elderly Living in Old Age Home and Within Family Set-up in Jammu. Stud Home Com Sci. (2011);5(2): 93-98

12. RP Thakur, A Banerjee and VB Nikumb. Health Problems Among the Elderly: A Cross-Sectional Study. Ann Med Health Sci Res. 2013;3(1): 19-25. doi: 10.4103/21419248.109466

13. Tiwari, S., Sinha, A., Patwardhan, K., Gehlot, S., \& Gambhir, I. S. Prevalence Of Health Problems Among Elderly: A Study In A Rural Population Of Varanasi. Indian J Community Med. (2010);41, 5.

14. WHO study 2015

15. Khole C. V, Soletti A. Nutritional Status of Elderly in the Old Age Homes: A Study in Pune City. Curr Res Nutr Food Sci 2018;6(1).doi :http://dx.doi.org/10.12944/CRNFSJ.6.1.27

16. A Mohapatra, SK Handoo, IS Gambhir, \& SC Mohapatra. A study of noncommunicable morbidity Pattern in geriatric patients attending a Referral railway hospital in Allahabad, Uttar Pradesh. Natl J Community Med. (2011); 2,2.

How to cite this article: Pooja Anudhar G, Sushma B. V. Socioeconomic, nutritional profile correlates with morbidity risks and quality of health status among elderly residing at old age home \& residence from different region of South Karnataka. Int J Health Sci Res. 2021; 11(6): 349-355. DOI: https://doi.org/10.52403/ ijhsr.20210652 